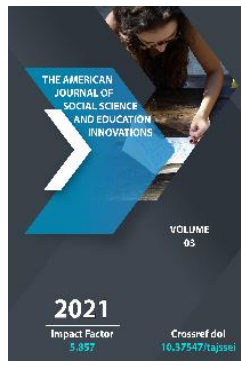

\section{Rethinking School Education: Important Aspects Of The Correct Construction Of The Development Trajectory Of Students}

\section{Mehriniso Pardaeva}

PhD., Republican Education Center Under The Ministry Of The People's Education Of The Republic Of Uzbekistan
Journal Website: http://usajournalshub.c om/index,php/tajssei

Copyright: Original content from this work may be used under the terms of the creative commons attributes 4.0 licence.

\title{
ABSTRACT
}

The global challenges of our time forced everyone to reconsider their views on the issue of teaching and educating the younger generation, especially schoolchildren. In a pandemic, the traditional organization of the educational process was impossible due to quarantine. No one was completely ready for such an outcome of circumstances, neither the educational system nor the parents, who always relied on teachers and entrusted them with the upbringing of their child.

\section{KEYWORDS}

School, education, educational system, traditional organization, educational process.

\section{INTRODUCTION}

It was necessary to change not only the format of the organization of the educational process for distance or mixed, but also teaching methods, methods of assessing student results.
Thus, there was a need for pedagogical transformation, rethinking the content, teaching methodology, reforms in the field of education, in particular in schools, developing, improving and increasing its resilience to 
various events, processes and challenges in learning.

Today there is a need to use traditional and non-traditional forms of organizing educational processes, to improve the quality of education in accordance with the requirements of a rapidly changing society on the basis of modern approaches to teaching.

We know from history that at the beginning of the twentieth century in most countries, the goal of school education was to teach people to read and write, and what happened in the first half of this period, for example, world and civil wars, various natural disasters and mass diseases adversely affected education.

In the 21st century, the goals of school education are changing, and the formation and development of students' literacy, competencies and personal qualities becomes a priority.

Both periods have a certain commonality, in which the stability of the school has been tested and verified until now, by natural and man-made phenomena, situations. This has its pros and cons, forcing humanity to take a critical look and rethink its own path of development.

\section{MATERIALS AND METHODS}

The pandemic shook the whole world, all of us, and many countries were stunned by the virus, which, despite its enormous technological and innovative achievements and supernatural power, humanity can suffer unprecedented socio-economic losses in a short period. This global challenge has shaped new demands in the field of school education, as in all other areas.

Due to the coronavirus, it became necessary to actively use distance or blended learning in the education system during the quarantine period. Although many consider this practice to be non-standard, something new, they express different attitudes, and this is not surprising.

But uncertainty, anxiety and fear of new technologies cannot hinder human development. Otherwise, humanity would have stopped its development even during the first scientific discoveries - it would be able to choose the most useful of the tools that it can use in any situation, and abandon the harmful ones. This is exactly what needs to be learned. The urgency of the problem is obvious, it is necessary to look for ways and solutions that make it possible to effectively build an educational trajectory, with the least loss in the

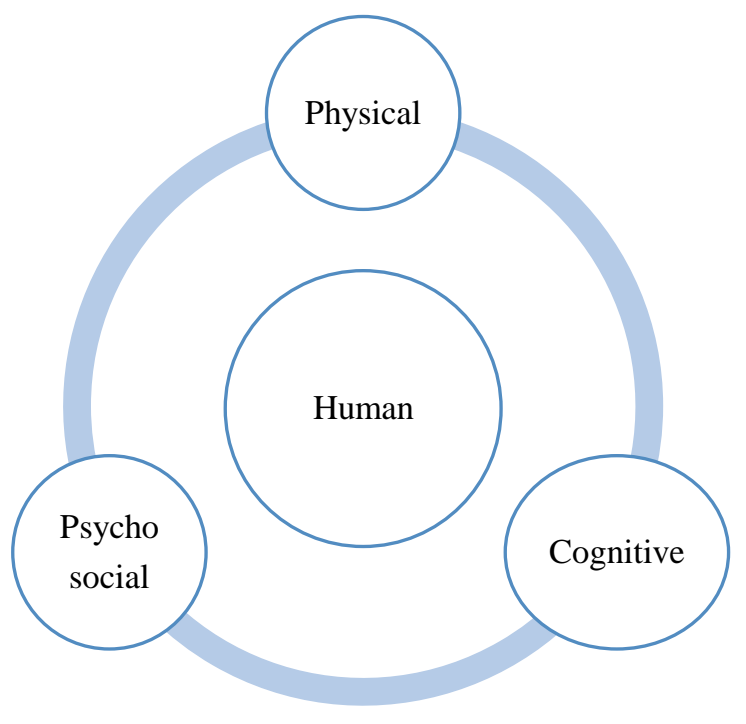

Figure 1: Spheres of Human Development 
quality of education. There are many factors, risks and situations that affect the outcome, for example, the physiological and psychological characteristics of students, the learning environment and conditions, educational resources and teaching methods, the assessment of learning outcomes and the support of teachers, parents, etc.

According to experts, each person goes through three areas of development from birth (Figure 1):

1) Physical - the growth and change of the body.

2) Cognitive - thinking, memory, imagination, speech perception.

3) Psychosocial - the development of personality and interpersonal relationships.

It is very important to provide support in all phases of development, which means education throughout life.

\section{RESULTS AND DISCUSSION}

The Sustainable Development Goals, formally known as Transforming Our World: The 2030 Agenda for Sustainable Development, is a set of goals for future international cooperation that replaced the Millennium Development Goals at the end of 2015. Specifically, Goal 4: Ensure inclusive and equitable quality education and promote lifelong learning opportunities for all, which is what we Uzbekistan are striving for [4].

$\checkmark$ To achieve this goal, it is necessary to ensure the continuity and continuity of all types of education: preschool, general secondary, vocational and higher education, which are based on state educational standards.

$\checkmark$ In accordance with the State Requirements for the Development of Children of Early and Preschool Age, which presents the expected result of the development of children from birth to 7 years old, and the State Curriculum "Ilkkadam", developed on the basis of international standards and using a competency-based approach, one can see the following:

$\checkmark$ The educational process in the preschool education system is integrated in 5 key areas of development: physical development and the formation of a healthy lifestyle; social and emotional development; creative development; cognitive development; speech, communication, reading and writing skills;

$\checkmark$ difference from the primary education system - there is no rigid objectivity;

$\checkmark$ the main type of child's activity is play, a personality-oriented approach is applied;

$\checkmark$ the goal of preschool education is the development of personal qualities of a preschooler (abilities): 4 competencies cognitive, play, communicative, social;

$\checkmark$ It is not worth the task to teach a preschooler to read, write and perform complex mathematical actions.

An important aspect is that the educational process in preschool organizations is carried out with the use of game technologies, each child has the opportunity to independently choose and the teachers carry out the introduction of cognitive tasks. The introduction of cognitive tasks is carried out on the basis of thematic planning and cognitive tasks are solved in various types of children's activities (drawing 2). 
The state program "Ilk Kadam" includes a "Map of the child's readiness for school" - the main goal of which is to determine the progress of the child's development and provide him with the opportunity to smoothly overcome the path in the main achievement of the desire to learn, not to teach.

Ensuring continuity between preschool and primary education is carried out in the National Curriculum for General Secondary Education, developed on the basis of advanced national and foreign experience, the implementation of which is planned for the 2021-2022 academic year in grades 1 and 2 .

Figure 2: Directions of the child's development

The need to improve the content of school education is due to the rapid development of science and technology in the world community, the processes associated with the fourth economic revolution, including the transition to the digital economy in Uzbekistan, cause new socio-economic, political and cultural changes. This, in turn, creates a strong competitive environment in all areas in the context of globalization and integration into the world. community, which in turn brings new demands on the schooling sector.

It is focused on developing 21st century skills in students based on international best practices, the requirements of international assessment programs. The curriculum of a new generation, will replace the previous one, based on the linear study of topics and within a certain subject, for example, children studied the world of plants in Grade 5 Botany, the animal world in Grade 6.7 in Zoology, and the evolution of man and his body in 8.9 grades and so on, separately. Such training in Biology led to the following problems:

First, the students formed knowledge in parts, which must be logically connected, for a holistic presentation, since in nature the evolution of plants, animals and humanity took place and is happening in a single space and is interconnected with each other. But not all students are capable of this.

Secondly, after graduation, graduates have to restore the forgotten knowledge about plants studied six years ago, knowledge about animals studied five years ago, etc., spending a lot of time and money visiting tutors. But not everyone has such an opportunity.

Thirdly, given the frequency of reprinting school textbooks, some of the previously acquired knowledge is simply lost and graduates have to master completely new educational material from the new textbook. But the new textbook may not be available to

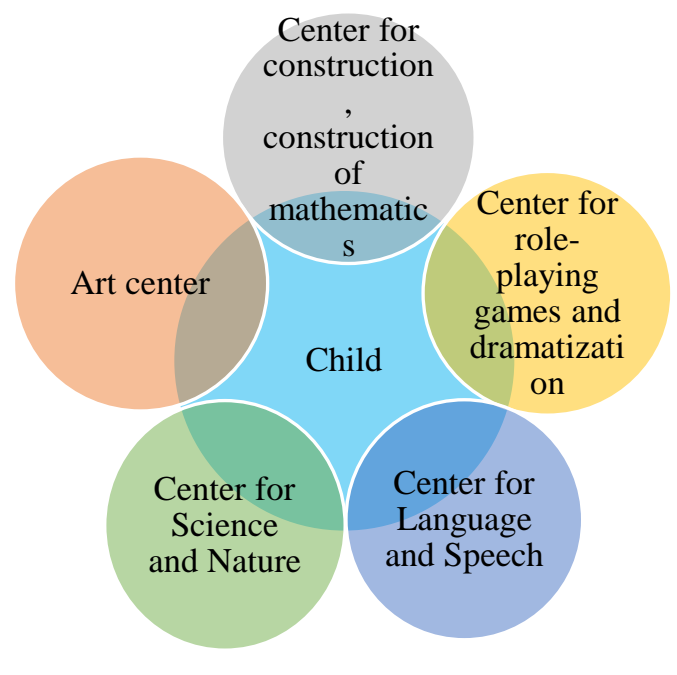

Figure 2: Directions of the child's development 
everyone, or just not everyone knows where to get them.

And also, the curriculum also requires the improvement and optimization of academic subjects, workload, taking into account the individual needs and abilities of students. The solution, which is the introduction of variable curricula with a choice of subjects, directions and in-depth study of individual subjects. Thus, opportunities expand and the chances of future graduates increase when entering higher education institutions.

To solve these and other problems, it is necessary to improve the content of the curriculum according to the principle of spiral learning, which form holistic and integrative knowledge, life skills and competencies in trainees. Continuity and interdisciplinary continuity and continuity between preschool and higher education is ensured.

New requirements for learning outcomes require improvement, and training methodology and assessment of learning outcomes. The existing format, form and methods of teaching, educational resources do not always provide an opportunity to form and develop modern skills that meet the requirements of the labor market and society. And the criteria for assessing the achievements of students to assess not only the amount of knowledge acquired, but also practical skills, abilities and competencies.

\section{CONCLUSION}

And so, the National Curriculum is a complex educational and regulatory document that has 6 main components, in general, it determines the requirements for the content, educational process, methodology and assessment of learning outcomes:

Требования к резельтатам учебной деятельности учащихся по классам и выпускнику;
Discipline Development Concept; Curriculum (basic and variable); Study programs in subjects; Teaching methodology; Assessment / evaluation.

It is expected that the National Curriculum will be gradually introduced from the 2021/2022 school year and fully implemented by the 20262027 school year and will serve to improve the quality of education in schools.

In conclusion, we can say that any reform in education, especially in school education, should have a clear strategy, a roadmap of actions and a development trajectory, scientific validity, and most importantly, it should correspond to national priorities and values, which can provide guaranteed results to give society competent, successful and sustainable citizen.

\section{REFERENCES}

1. Concept for the development of the public education system of the Republic of Uzbekistan until 2030. Decree of the President of the Republic of Uzbekistan dated April 29, 2019 No. UP-5712.

2. State curriculum "Ilkkadam" for preschool educational institutions. https://www.unicef.org/uzbekistan/media 13766. 
The American Journal of Social Science and Education Innovations (ISSN - 2689-100x)

Published: April 30, 2021 | Pages: 510-515

Doi : https://doi.org/10.37547/tajssei/Volume03Issue04-82

2021: 5.857

3. Draft National Curriculum for General Secondary Education in Uzbekistan. https://t.me/dastur_muhokamasi.

https://www.un.org/sustainabledevelopm ent/ru/education. 